\title{
University of Florida Potato Variety Trial Spotlight: “Goldrush'1
}

\author{
Mario H. M. L. Andrade, Rodrick Z. Mwatuwa, Christian T. Christensen, Pam Solano, Lincoln \\ Zotarelli ${ }^{2}$
}

There are several potato varieties available in the market today. Most of them have been bred or developed in production regions other than Florida. The University of Florida Potato Variety Evaluation Program screens new germplasm from public and private breeding programs and identifies the most promising cultivars for commercial potential considering broad adaptability to Florida climate and conditions and market purpose: processing, freshmarket and specialty-type varieties. Over the years, the UF/ IFAS Potato Variety Program has become an important reference to vegetable growers, seed producers, processors, crop insurance agencies, and brokers looking for alternative potato varieties to explore different markets, improved characteristics, and yield. This UF/IFAS Potato Variety Trials Spotlight presents a summary of the field evaluation of tuber yield and quality performance of the potato variety 'Goldrush' cultivated in Florida.

\section{General Comments}

'Goldrush' is a russet potato variety commonly grown for the fresh potato market, particularly for baking and boiling. It was selected from the progeny of a cross between ND4503Russ and Lemhi Russet at North Dakota State University (Johansen et al. 1993). It was released in 1992 from the North Dakota Agricultural Experiment Station. 'Goldrush' demonstrates high yield and good tuber characteristics compared to its commercial standard 'Atlantic'. Tuber production and quality results provided in this spotlight are summarized from various trials conducted by the UF/IFAS Hastings Agricultural and Extension Center from 2005 to 2019, except 2012.

\section{General Characteristics}

'Goldrush' tubers have a brown skin with oblong to long shape and white flesh color (Figure 1). According to Florida rating codes for potato tuber characteristics (Table 1), the tubers have a good appearance with a moderate russet skin and intermediate to shallow eye depth. 'Goldrush' has demonstrated high yield potential under Florida production conditions (Tables 2 and 3). On average, marketable yield is $218 \mathrm{cwt} / \mathrm{acre}$, approximately $6 \%$ below the commercial standard 'Red LaSoda', with $75 \%$ of the tubers produced found between classes $\mathrm{A} 1$ and $\mathrm{A} 3$ size distribution classes. It has a low to medium specific gravity of 1.061 (Table 2).

1. This document is HS1299, one of a series of the Horticultural Sciences Department, UF/IFAS Extension. Original publication date May 2017. Revised April 2020 and February 2021. Visit the EDIS website at https://edis.ifas.ufl.edu.

2. Mario H. M. L. Andrade, research scholar; Rodrick Z. Mwatuwa, research assistant; Christian T. Christensen, postdoctoral research associate; Pam Solano, biological scientist; and Lincoln Zotarelli, assistant professor; Horticultural Sciences Department, UF/IFAS Extension, Gainesville, FL 32611.

The Institute of Food and Agricultural Sciences (IFAS) is an Equal Opportunity Institution authorized to provide research, educational information and other services

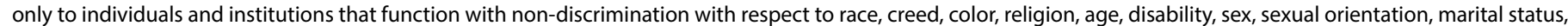

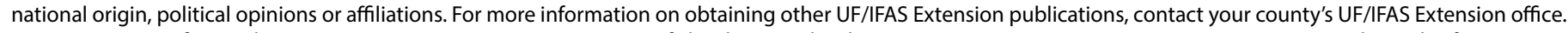
U.S. Department of Agriculture, UF/IFAS Extension Service, University of Florida, IFAS, Florida A \& M University Cooperative Extension Program, and Boards of County Commissioners Cooperating. Nick T. Place, dean for UF/IFAS Extension. 


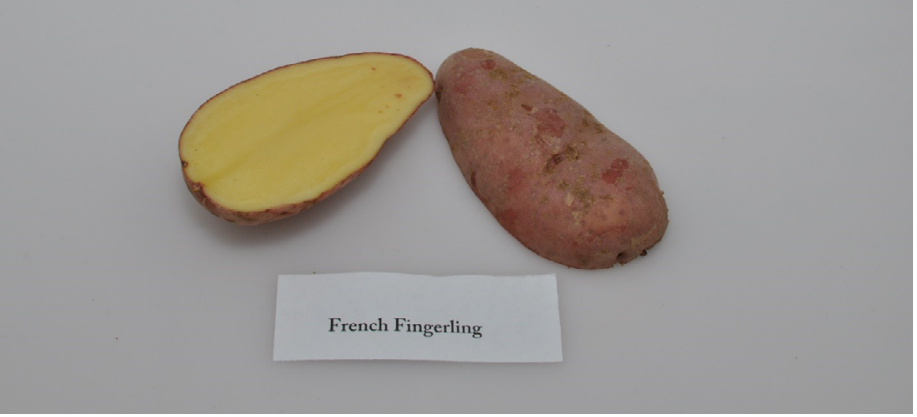

Figure 1. Typical tuber and internal flesh color of 'Goldrush' variety. Credits: Lincoln Zotarelli, UF/IFAS

\section{Diseases}

'Goldrush' demonstrates a slight susceptibility to corky ringspot and internal heat necrosis under Florida conditions (Table 3). It is resistant to common scab (Streptomyces scabies) and moderately resistant to Verticillium wilt (Verticillium albo-atrum and Verticillium dahliae), silver scurf (Helminthosporium solani), and blackspot bruising. 'Goldrush' is susceptible to most common potato viruses and other diseases such as mosaic, early blight (Alternaria solani), late blight (Phytophthora infestans), soft rot (Pectobacterium spp.), and fusarium dry rot (Fusarium spp.). The standard UF/IFAS Extension recommended disease and weed control program described under Potato Production (Chapter 14 of the Vegetable Production Handbook for Florida, http://edis.ifas.ufl.edu/cv131) should be followed.

\section{Season Length and Growth}

'Goldrush' is a medium-maturing cultivar under Florida growing conditions. Season length was 94 days on average from planting to harvest. This depended on weather conditions during the growing season. The plants should be harvested two to three weeks after vine kill to improve tuber maturation and skin set. Potatoes with proper skin set maintain better skin color, lose less weight in storage, and are more resistant to bruising and soft rot. For more information about vine killing on potatoes, see Potato Vine Killing or Desiccation (Zotarelli et al. 2016). Late in the season, tuber size should be checked regularly to harvest tubers with desirable, marketable size. Soil moisture should be managed late in the season to avoid high soil moisture conditions that cause enlarged lenticels and delayed skin set.

\section{Fertilization}

UF/IFAS trial plots are normally fertilized with 200 to 230 $\mathrm{lb} / \mathrm{A}$ of $\mathrm{N}$. The first application of $100 \mathrm{lb} / \mathrm{A}$ of $\mathrm{N}$ (granular) is typically incorporated in the bed prior to planting, followed by one or two side-dress fertilizer applications at emergence and/or at tuber initiation. Phosphorus and potassium applications follow the UF/IFAS guidelines described in Liu et al. (2019) and normally range between 45 to $100 \mathrm{lb} / \mathrm{A}$ of $\mathrm{P}_{2} \mathrm{O}_{5}$ and 170 to $235 \mathrm{lb} / \mathrm{A}$ of $\mathrm{K}_{2} \mathrm{O}$.

\section{Planting}

A seed piece of 2.5 to $3 \mathrm{oz}$ is recommended for planting. This variety should be planted with 40 inches between rows and 8 inches between plants, at 3 to 4 inches deep. A seed rate of 2,000 to $3,000 \mathrm{lb} /$ acre of seed is expected.

\section{Other Information}

For additional information on cultivation and weed and disease management see the Potato Production chapter of the Vegetable Production Handbook, available at http://edis. ifas.ufl.edu/cv131.

\section{References}

David, D. 2020. Vegetable Cultivar Descriptions for North America. Cucurbit Breeding Program, Horticultural Science. Michigan State University. http://cucurbitbreeding. com/todd-wehner/publications/vegetable-cultivardescriptions-for-north-america/potato/. Accessed on 23 April 2020.

Hutchinson, C. M., J. M. White, D. M. Gergela, P. A. Solano, K. G. Haynes, R. Wenrich, and C. S. Lippi. 2003. "Performance of chip processing potato varieties in northeastern Florida." HortTechnology 13 (4): 706-711.

Johansen, R. H., B. L. Farnsworth, G. A. Secor, N. C. Gudmestad, and A. Thompson-Johns. 1993. "Goldrush: a new russet potato variety." North Dakota Farm Research (USA). https://library.ndsu.edu/ir/bitstream/handle/10365/9617/ farm_50_01_08.pdf? sequence=1. Accessed on 23 April 2020 .

Liu, G., E. H. Simonne, K. T. Morgan, G. J. Hochmuth, S. Agehara, and R. Mylavarapu. 2019. Chapter 2. Fertilizer Management for Vegetable Production in Florida. In Vegetable Production Handbook for Florida, 2019-2020 Edition. CV296. Gainesville: University of Florida Institute of Food and Agricultural Sciences. http://edis.ifas.ufl.edu/cv296

Sisson, J. A., and G. A. Porter. 2002. "Performance evaluations of potato clones and varieties in the northeastern states-1999." Maine Agr. For. Expt. Sta., Misc. Publ. 751. 
The Potato Association of America. 2017. “'Goldrush'

(Solanum tuberosum)." The Potato Association of America. https://www.potatoassociation.org/varieties/russet-potatovarieties/goldrush-solanum-tuberosum/. Accessed on 22 April 2020.

Zotarelli, L., P. J. Dittmar, P. D. Roberts, P. J. Desaeger, B. Wells, and S. E. Webb. 2020. Chapter 14. Potato Production. In Vegetable Production Handbook for Florida, 2020-2021 Edition. HS733. Gainesville: University of Florida Institute of Food and Agricultural Sciences. http://edis.ifas.ufl.edu/ cv131

Zotarelli, L., S. Sargent, P. Dittmar, and M. Makani. 2016. Potato Vine Killing or Desiccation. HS181. Gainesville: University of Florida Institute of Food and Agricultural Sciences. http://edis.ifas.ufl.edu/hs181

Table 1. Florida's rating codes for potato vine maturity and tuber characteristics at harvest.

\begin{tabular}{|c|c|c|c|c|c|c|c|}
\hline \multicolumn{8}{|c|}{ Tuber Characteristics $^{1}$} \\
\hline $\begin{array}{c}\text { Rating } \\
\text { Code }\end{array}$ & $\begin{array}{c}\text { Vine } \\
\text { Maturity }\end{array}$ & $\begin{array}{l}\text { Internal } \\
\text { Flesh Color }\end{array}$ & Skin Color & Skin Texture & Tuber Shape & Eye Depth & Overall Appearance \\
\hline 1 & dead & white & purple & partial russet & round & very deep & very poor \\
\hline 2 & +- & cream & red & heavy russet & mostly round & -- & -- \\
\hline 3 & $\begin{array}{c}\text { yellow and } \\
\text { dying }\end{array}$ & light yellow & pink & moderate russet & round to oblong & deep & poor \\
\hline 4 & +- & $\begin{array}{l}\text { medium } \\
\text { yellow }\end{array}$ & dark brown & light russet & mostly oblong & -- & -- \\
\hline 5 & $\begin{array}{c}\text { moderately } \\
\text { senesced }\end{array}$ & dark yellow & brown & netted & oblong & intermediate & fair \\
\hline 6 & +- & pink & $\tan$ & slightly netted & oblong to long & -- & -- \\
\hline 7 & $\begin{array}{l}\text { starting to } \\
\text { senesce }\end{array}$ & red & buff & $\begin{array}{l}\text { moderately } \\
\text { smooth }\end{array}$ & mostly long & shallow & good \\
\hline 8 & +- & blue & white & smooth & long & -- & -- \\
\hline 9 & $\begin{array}{l}\text { green and } \\
\text { vigorous }\end{array}$ & purple & cream & very smooth & cylindrical & very shallow & excellent \\
\hline
\end{tabular}


Table 2. Summary of production statistics and specific gravity of 'Goldrush' potato variety grown at the UF/IFAS Hastings Agricultural Extension Center, Hastings, FL from 2005 to 2019 excluding 2012.

\begin{tabular}{|c|c|c|c|c|c|c|c|c|c|c|c|c|c|}
\hline \multirow[t]{2}{*}{ Year } & \multirow{2}{*}{$\begin{array}{l}\text { Total } \\
\text { Yield } \\
\text { (cwt/ac) }\end{array}$} & \multirow{2}{*}{$\begin{array}{l}\text { Marketable } \\
\text { Yield } \\
\text { (cwt/ac) }\end{array}$} & \multirow{2}{*}{$\begin{array}{c}\% \text { of } \\
\text { Standard }\end{array}$} & \multirow[t]{2}{*}{ Standard } & \multicolumn{6}{|c|}{ Size Class (Distribution by class \%) } & \multicolumn{2}{|c|}{ Range \% } & \multirow{2}{*}{$\begin{array}{l}\text { Specific } \\
\text { Gravity }\end{array}$} \\
\hline & & & & & C & B & A1 & $\mathbf{A 2}$ & A3 & A4 & $\begin{array}{c}\text { A1 to } \\
\text { A3 }\end{array}$ & Culls & \\
\hline 2005 & 295 & 250 & $96 \%$ & Red LaSoda & 2 & 13 & 69 & 14 & 2 & 0 & 85 & 1 & 1.067 \\
\hline 2006 & 379 & 320 & $90 \%$ & Red LaSoda & 1 & 12 & 72 & 13 & 3 & 0 & 87 & 3 & 1.067 \\
\hline 2007 & 396 & 323 & $84 \%$ & Red LaSoda & 2 & 13 & 74 & 8 & 3 & 0 & 85 & 4 & 1.059 \\
\hline 2008 & 353 & 251 & $93 \%$ & Red LaSoda & 2 & 24 & 58 & 16 & 0 & 0 & 74 & 4 & 1.069 \\
\hline 2009 & 400 & 338 & $106 \%$ & Red LaSoda & 2 & 12 & 80 & 6 & 0 & 0 & 86 & 3 & 1.056 \\
\hline 2010 & 344 & 238 & $81 \%$ & Red LaSoda & 5 & 23 & 67 & 5 & 0 & 0 & 72 & 5 & 1.063 \\
\hline 2011 & 319 & 239 & $85 \%$ & Red LaSoda & 3 & 16 & 77 & 4 & 0 & 0 & 80 & 7 & 1.069 \\
\hline 2013 & 289 & 232 & $157 \%$ & Red LaSoda & 2 & 13 & 69 & 11 & 4 & 0 & 85 & 4 & 1.058 \\
\hline 2014 & 289 & 172 & $89 \%$ & Red LaSoda & 5 & 32 & 57 & 5 & 1 & 0 & 63 & 6 & 1.055 \\
\hline 2015 & 236 & 130 & $77 \%$ & Red LaSoda & 8 & 28 & 63 & 1 & 0 & 0 & 64 & 17 & 1.060 \\
\hline 2016 & 262 & 186 & $185 \%$ & Red LaSoda & 3 & 21 & 71 & 4 & 1 & 0 & 76 & 7 & 1.067 \\
\hline 2017 & 160 & 73 & $51 \%$ & Red LaSoda & 13 & 39 & 49 & 0 & 0 & 0 & 49 & 6 & 1.051 \\
\hline 2018 & 198 & 101 & $51 \%$ & Red LaSoda & 13 & 35 & 48 & 3 & 2 & 0 & 52 & 2 & 1.056 \\
\hline 2019 & 248 & 203 & $68 \%$ & Red LaSoda & 4 & 11 & 57 & 26 & 2 & 0 & 85 & 4 & 1.063 \\
\hline Average & 298 & 218 & $94 \%$ & & 5 & 21 & 65 & 8 & 1 & 0 & 75 & 5 & 1.061 \\
\hline \multicolumn{14}{|c|}{$\begin{array}{l}{ }^{1} \text { Marketable yield: Sum of size classes } A 1 \text { to } A 3 \text {. } \\
{ }^{2} \text { Size classes: } C=0.5 \text { to } 1.5 \text { inches, } B=1.5 \text { to } 17 / 8 \text { inches, } A 1=17 / 8 \text { to } 2.5 \text { inches, } A 2=2.5 \text { to } 3.25 \text { inches, } A 3=3.25 \text { to } 4 \text { inches, } A 4>4 \text { inches; } \\
\text { Size distribution by class: Class (wt)/(Total Yield [wt] - culls [wt]) }\end{array}$} \\
\hline
\end{tabular}

Table 3. Yield, vine maturity, tuber characteristics, and internal tuber defects of 'Goldrush' potato variety grown at the UF/IFAS Hastings Agricultural Extension Center, Hastings, FL from 2005 to 2019, excluding 2012.

\begin{tabular}{|c|c|c|c|c|c|c|c|c|c|c|c|}
\hline \multirow[t]{2}{*}{ Year } & \multirow{2}{*}{$\begin{array}{c}\text { Vine } \\
\text { Maturity } \\
\text { (Vine Kill) }\end{array}$} & \multicolumn{6}{|c|}{ Tuber Characteristics ${ }^{1}$} & \multicolumn{4}{|c|}{ Internal Defects ${ }^{2}$} \\
\hline & & $\begin{array}{l}\text { Internal } \\
\text { Flesh } \\
\text { Color }\end{array}$ & Skin Color & $\begin{array}{l}\text { Skin } \\
\text { Texture }\end{array}$ & $\begin{array}{l}\text { Tuber } \\
\text { Shape }\end{array}$ & $\begin{array}{c}\text { Eye } \\
\text { Depth }\end{array}$ & $\begin{array}{c}\text { Overall } \\
\text { Appearance }\end{array}$ & HH & BR & CRS & IHN \\
\hline 2005 & 7 & 2 & 5 & 2 & 5 & 8 & 7 & 0 & 0 & 0 & 0 \\
\hline 2006 & 9 & 2 & 4 & 2 & 5 & 7 & 7 & 0 & 0 & 0 & 0 \\
\hline 2007 & 6 & 1 & 4 & 2 & 6 & 7 & 7 & 0 & 0 & 0 & 0 \\
\hline 2008 & 6 & 1 & 5 & 3 & 5 & 7 & 6 & 0 & 0 & 0 & 0 \\
\hline 2009 & 4 & 2 & 5 & 3 & 4 & 5 & 6 & 0 & 0 & 0 & 0 \\
\hline 2010 & 8 & 1 & 5 & 2 & 5 & 6 & 7 & 0 & 0 & 0 & 0 \\
\hline 2011 & 3 & * & * & * & * & * & 6 & 0 & 0 & 28 & 8 \\
\hline 2013 & 2 & 1 & 5 & 3 & 6 & 7 & 6 & 0 & 0 & 0 & 0 \\
\hline 2014 & 6 & 1 & 5 & 2 & 5 & 6 & 6 & 0 & 0 & 3 & 1 \\
\hline 2015 & 5 & 1 & 6 & 3 & 6 & 9 & 8 & 0 & 0 & 0 & 0 \\
\hline 2016 & 6 & 1 & 5 & 3 & 6 & 7 & 7 & 0 & 0 & 0 & 1 \\
\hline 2017 & 6 & 1 & 5 & 3 & 6 & 8 & 8 & 0 & 0 & 0 & 0 \\
\hline 2018 & 4 & 1 & 5 & 3 & 6 & 8 & 8 & 0 & 0 & 0 & 0 \\
\hline 2019 & 6 & 1 & 5 & 4 & 6 & 8 & 8 & 0 & 0 & 0 & 0 \\
\hline Average & 6 & 1 & 5 & 3 & 6 & 7 & 7 & 0 & 0 & 2 & 1 \\
\hline
\end{tabular}

